\title{
Peningkatan Hasil Belajar Siswa melalui Model Pembelajaran Mind Mapping \\ Pada Tema 8 Subtema 1 Manusia dan Lingkungan Kelas V SD
}

\author{
Nela Rofisian, S.Pd., M.Pd ${ }^{1}$, Ummu Hany Almasitoh, S.Psi., MA ${ }^{2}$ \\ PGSD, Universitas Widya Dharma Klaten, Indonesia \\ Email: 1'rofisian@yahoo.co.id, ${ }^{2}$ mawar_41hany@yahoo.co.id
}

\begin{abstract}
Abstrak
Mind mappingmengembangkan tingkatkeaktifan, kreatifitas, daya ingat, kemandirian danpengetahuansiswasesuaidengan tujuan pembelajaran yang ingin dicapai. Mind Mapping dapat membuat hasil belajar meningkat dan keaktifan siswa di kelas V SDN Sribit dalam pembelajaran IPS, dibuktikan dengan meningkatnyahasil belajar siswa berdasarkan kriteria keberhasilan tindakan yaitu $\geq 50 \%$ dari jumlah seluruh siswa kelas V mencapai nilai KKM 75. Pada kondisi awal (Pra Siklus) nilai rata-rata hasil belajar siswa kelas V SDN Sribit sebesar 68,30atau sebesar $26,92 \%$. Hasil belajar siswa yang rendah terlihat dari proses pembelajaran yang didominasi oleh guru,siswa terbiasa duduk mendengarkan penjelasan guru sehingga permasalahan tersebut menyebabkan siswa kurang akif dalam pembelajaran, menurunnya semangat belajar siswa. Dengan adanya perbaikanpada siklus 1 rata-rata hasil belajar siswa mengalami peningkatan sebesar 72,46 danketuntasan belajar siswa mencapai 46,15\%.Selanjutnya pada siklus 2 hasil belajar siswa mengalami peningkatansebesar 77,23 dan ketuntasan belajar siswa mencapai $76,92 \%$.
\end{abstract}

\section{PENDAHULUAN}

Pendidikan berperan penting pada pembangunan suatu bangsa. Hal ini disebabkan karena pendidikan mampu menciptakan generasi yang cerdas, berwawasan, terampil, berkualitas, dan dapat memberi perubahan bangsa yang lebih baik.Guru memiliki peran utama dalam menentukan kualitas dalam pembelajaran yang dilaksanakan.Hal yang perlu diperhatikan dalam pembelajaran adalah pemilihan metode, media, penggunaan sumber belajar, profesionalisme guru, dan sebagainya. Penggunaan media dan model yang bervariasi akan memberikan dampak positif terhadap pemahaman siswa mengenaisesuatu hal yang dipelajari.Mind mappingadalah pembelajaran inovatif yang menjadikan siswa terlibat aktif pada proses pembelajaran. Mind mapping merupakan pembelajaran yang dilakukan oleh siswa dengan membuat peta pikiran (mind map), sehingga siswa mampu mengidentifikasi secaratepat dan berkreasi tentang materi yang dipelajari atau yang direncanakan.

Berdasarkan hasil observasi awal di SD Sribit terlihat bahwa model pembelajaran yang digunakan dalam kegiatan pembelajaranbersifat konvensional dan siswa kebanyakan tidak merespon guru ketika diberi kesempatanuntuk mengajukan pertanyaantentanghal yang belum dipahami pada materi. Dalam proses pembelajaran siswa merasa cepat bosan karena minimnya media pembelajaran yang digunakan oleh guru. Sebagianstrategidan model pembelajaranyang berbasis kelompok sudahditerapkan, tetapi hasilnya tidak 
sesuai harapan. Hal tersebut disebabkan karena siswa kurang aktif pada saat pembelajaranberlangsung dan siswacenderung bergantung pada hasil pekerjaan temannya ketika diskusi kelompok, masalah tersebut dapat memengaruhi hasil belajar siswa. Berdasarkan hasil ulangan harian tema 6 subtema 3 terdapat $\leq 50 \%$ siswa yang mencapaiketuntasan yaitu sesuai dengan kriteria ketuntasan minimal pada masing-masing mata pelajaran, selain itu jarak nilai siswa cukup signifikan antara yang tertinggi dengan yang terendah. Hal tersebut disebabkan karena kurang bervariasinyamodel pembelajaran yang diterapkan guru sehingga menyebabkan siswa pasif dan kreativitasnya terbatas.Hal tersebut dapat diatasi dengan mengembangkan model pembelajaran yang mampu meningkatkan motivasi, kreativitas dan aktivitas belajar siswa.Salah satunya dengan menerapkan Mind Mapping dalam pembelajaran di sekolah.Model pembelajaran inovatifMind mapping melibatkan siswa agar aktif dalam kegiatan pembelajaran di sekolah. Penggunaanmind mapping dalam pembelajaran diharapkan mampu menumbuhkan tingginya interaksiguru dan siswa atau antara siswa itu tersebut. Hal tersebutdapat membuatiklimbelajar di kelas menjadi aktif dan lebih kondusif.Siswa mampu menunjukkan kompetensinya secara maksimal dengan melakukan berbagai aktivitas belajar yang ditunjukkan melalui bermacam-macam kegiatan pada waktu proses pembelajaran berlangsung. Aktivitas belajar yang dimunculkan siswa dapat membentuk pengetahuan dan keterampilan yang dapat meningkatkan hasil belajar di sekolah. Berdasarkan penjelasan tersebut, peneliti membuat penelitian yang berjudul
"Peningkatan Hasil Belajar Siswa Melalui Model Pembelajaran Mind Mapping Pada Tema 8 Sub Tema 1 Manusia dan Lingkungan Kelas V SD."

\section{METODE}

A. Jenis dan Desain Penelitian

Jenis penelitian ini adalah Classroom Action Research (Penelitian Tindakan Kelas)yang merupakansebuah kajian yang reflektif oleh pelaksana tindakan dengan tujuan agar kemampuan dari tindakantindakan yang dilakukan meningkatkan dan kondisi-kondisi di mana praktek-praktek pembelajaran yang dilakukan dapat diperbaiki.Sesuai dengan hakikat penelitian tindakan kelas, maka penelitian ini dilaksanakan secara kolaborasi dalam situasi tim kerja, sejak tahap perencanaan, tindakan, observasi, dan refleksi.

Desain penelitian dalam penelitian ini adalah model Kemmis \& Taggart (1988: 14).Tiapsiklus meliputi empat tahap, yaitu perencanaan, tindakan, observasi, dan refleksi.Tujuan dari tahapan tersebut adalah jika di awal pelaksanaan tidakan terdapat kekurangan makapada tahap atau siklus berikutnya dapat dilakukan perbaikan hinggatujuan yang diharapkan tercapai.

B. Lokasi dan Waktu Penelitian

Lokasi pelaksanaan penelitian ini di SD Sribit, Bantul, DIY.Kegiatan penelitian ini dilaksanakan bulanFebruari 2018 sampai April 2018.

C. Subjek dan Objek Penelitian

Subjek pada penelitian ini yaitu siswa kelas V SD Sribit sebanyak 26 siswa, meliputi 15 siswi dan 11 siswa, serta melibatkan guru kelas $\mathrm{V}$ sebagai pelaksanan tindakan dan rekan sejawat sebagai observer bersama dengan peneliti. Objek pada 
penelitian ini yaitu peningkatan hasil belajar siswa.

D. Teknik dan Instrumen Pengumpulan Data

Peneliti memakai beberapa teknik dan alat dalam pengumpulan data, yaitu observasi dengan lembar observasi, dokumentasi dengan foto, wawancara dengan pedoman wawancara, tes hasil belajar dengan soal, dancatatan lapangan.

E. Teknik Analisis Data

Penelitian ini menggunakan data kualitatif.Data penelitian ini dianalisis dengan cara merefleksikan hasil observasi saat pelaksanaan tindakan pada setiap siklus. Proses ini berjalan secara kolaboratif antara peneliti, pengamat, dan guru untuk melihat, menganalisis, memberi nilai dan mempertimbangkan dampak serta hasil tindakan pada saat proses hasil yang dicapai dari tindakan yang telah terlaksana.Teknik pengolahan data pada penelitian ini adalah teknik triangulasi data.

\section{HASIL PENELITIAN DAN PEMBAHASAN}

a. Pra Siklus

Menurut hasil observasi pada pra tindakan penelitian, kegiatan belajar mengajar bersifat konvensional. Siswa diam, duduk danmendengarkan guru menyampaikan materi. Siswa yang duduk di belakang dan ditengah terlihat ada beberapa yang ngobrol dan bercanda dengan teman sebangkunya, kurangnya kesempatanyang diberikan pada siswa untuk menyampaikan pendapat, sehingga hal tersebut membuat siwa kurang aktif, hasil belajardansemangat siswa menjadi rendah. Siswa masih terlihat pasifpada pembelajaran ini dan pada pra siklus hasil belajar siswasebesar68,30 nilai tertinggi 100 dan nilai terendah 57. Selain itu siswa yang mencapai ketuntasan belajar baru sekitar $26,92 \%$.

Setelah dilakukan pengamatan langsung pada kegiatan pembelajaran di kelas $\mathrm{V}$ pada tahap pra siklus, peneliti berdiskusi dengan guru kelas dalam membuat rencana pada siklus 1.

b. Siklus I

Berdasarkan tes yang dilaksanakan pada akhir pembelajaran pada siklus 1, didapat hasil belajar dengan rata-rata sebesar 72,46 dengan demikian maka dapat diketahui bahwa hasil belajar siswa meningkat pada siklus 1. Rata-rata hasil belajar siswa tersebut sudah berada di atas standar KKM yang telah ditentukan yaitu 75. Selain itu menurut data yang diperoleh pada siklus 1 terdapat 14 siswa dengan nilai di bawah KKM yang telah ditentukan. Namun demikian pada siklus 1 ini siswa yang hasil belajarnya mencapai KKM mengalami peningkatan menjadi 12 siswa atau ketuntasan belajar siswa mencapai sekitar 46,15\%.

c. Siklus II

Berdasarkan tes yang dilaksanakan pada akhir pembelajaran pada siklus 2 didapat rata-rata hasil belajar sebesar 77,23 dengan demikian maka dapat diketahui bahwa pada siklus 2terdapat peningkatan hasil belajar siswa. Rata-rata hasil belajar tersebut sudah berada di atas standar KKM yang telah ditentukan yaitu 75. Selain itu pada siklus 2 ini siswa yang hasil belajarnya mencapai KKM mengalami peningkatan menjadi 20 siswa atau ketuntasan belajar siswa mencapai sekitar 76, 92 \%. Namun demikian menurut data yang diperoleh pada siklus 2 masih terdapat 6 siswa dengan nilai hasil belajar yang masih di bawah KKM yang telah ditentukan. 


\section{Pembahasan Hasil Penelitian}

\section{Hasil Belajar Siswa}

Sebelum dilakukan pembelajaran denganMind Mappingdiketahui bahwa hasil belajar siswa kelas V SDN Sribit masih belum tuntas sesuai dengan KKM yang diharapkan yaitu 75. Hal ini disebabkan oleh proses pembelajaran masih bersifat konvensional terpusat pada guru. Siswa dudukdan mendengarkan gurumenyampaikan materi, sehingga menyebabkan siswa menjadi bosan dan tidak semangat untuk mengikuti kegiatan pembelajaran. Rendahnya semangat belajar siswa tersebut sangat mempengaruhi hasil belajar siswa.

Setelah dilakukan tindakan perbaikan pembelajaran melalui pembelajaranMind Mapping, terlihat hasil belajar siswa meningkat dari siklus ke siklus. Hal ini disebabkan siswa turut aktif dalam kegiatan belajar di kelas. Mind Mappingadalah strategi peninjauan kembali (pengulangan) materi, yang menjadikan siswa mmpu mengingat ulang materi yang telah dipelajarinya. Model pembelajaran ini mengandung unsur pembelajaran aktif inovatif sehingga siswa senang dan tidak jenuh dalam kegiatan pembelajaran.

Hasil belajar siswa yang meningkat dapat diamatimelaluigrafik di berikut ini.

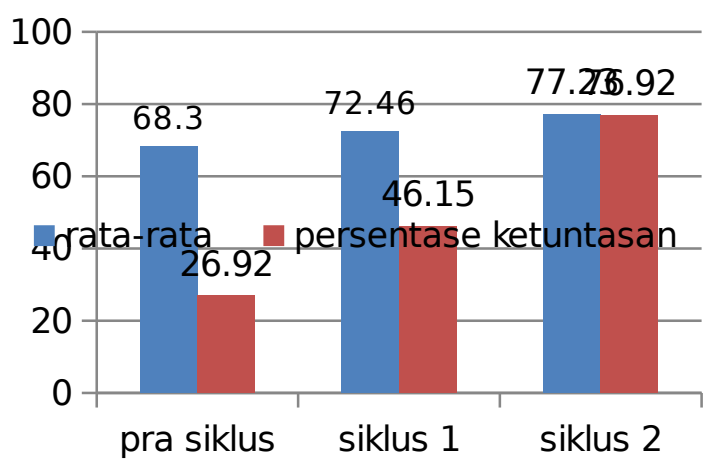

Gambar 1. Grafik Hasil Belajar Siswa dari Siklus ke Siklus

Gambar 1memperlihatkandari siklus ke siklus berikutnya, hasil belajar siswa meningkat.Sebelum dilakukan pembelajaran dengan model pembelajaranMind Mappinghasil belajar siswa kelas V SDN Sribitmencapai rata-ratasebesar 68,30 dengan persentase ketuntasan belajar hanya sebesar $26,92 \%$. Setelah dilakukan tindakan perbaikanpembelajaran melalui model Mind Mapping, hasil belajar siswa meningkat dengan rata-rata sebesar 72,46. Pada siklus 1 ini hasil belajar siswa mengalami peningkatan sebesar 4,16 dari sebelum dilakukan tindakan. Persentase ketuntasan hasil belajar siswa juga meningkat sebesar 19,23pada siklus 1, yaitu menjadi sebesar $46,15 \%$. Selanjutnya di siklus 2 hasil belajar siswa meningkat dengan rata-rata sebesar 77,23 . Hasil belajar siswa pada siklus 2 ini mengalami peningkatan sebesar 4,77 dari siklus 1. Persentase ketuntasan hasil belajar siswa juga meningkatmenjadi30,77pada siklus 2 , yaitu menjadi sebesar $76,92 \%$.

\section{KESIMPULAN}

Pembelajaran Mind mappingmampu mengembangkan tingkat keaktifan, kreatifitas, daya ingat,kemandirian dan pengetahuan siswa untuk mencapai tujuan pembelajaran.Mind Mapping mampumembuat hasil belajar siswa di Kelas V SDN Sribit meningkatkan dalam Pembelajaran IPS, terbukti dengan hasil belajar siswa yang meningkat sesuai dengan kriteria keberhasilan tindakan yaitu $\geq 50 \%$ dari jumlah seluruh siswa kelas $\mathrm{V}$ mencapai nilai KKM 75. Pada kondisi awal (Pra Siklus) ketuntasan hasil belajar siswa masih belum tuntas sesuai dengan KKM yang diharapkan 
yaitu 75. Setelah dilaksanakan tindakan pada Siklus 1 dan Siklus 2 terbukti pembelajaran melalui modelmind mapping hasil belajar siswa meningkat dari siklus ke siklus.

Rata-rata hasil belajar siswa kelas V SDN Sribit pada tahap pra siklusyaitu 68,30 danketuntasan belajar hanya sebesar 26,92\%. Setelah dilakukan perbaikanpembelajaran pada Siklus I hasil belajar siswa meningkat sebesardengan rata-rata72,46 danketuntasan belajar siswa sebesar 46,15\%.Selanjutnya pada siklus 2 hasil belajar siswa meningkat dengan rata-rata sebesar 77,23 dandanketuntasan belajar siswa mencapai 76,92\%.Hal ini disebabkan karena siswa turut aktif dalam kegiatan pembelajaran menggunakan model Mind Mapping.

\section{DAFTAR PUSTAKA}

Buzan, Tony. (2013). Buku Pintar Mind Mapping. Gramedia Pustaka Utama: Jakarta.

Dimyati dan Mudjiono. (2013). Belajar dan Pembelajaran. Rineka Cipta: Jakarta.

Guspriyanto, Yudy. (2012). Pengaruh Penerapan Metode Pembelajaran "MIND MAPPING" terhadap Minat Belajar dan Hasil Belajar IPS Siswa Kelas IV Sekolah Dasar. Skripsi diterbitkan Universitas Kristen Satya Wacana: Salatiga. (Sumber: http://repository.uksw.edu/ handle/123456789/1009 diunduh pada Senin, 14 Maret 2016 Pukul 10.45 WIB).
Kemmis, S dan R. Mc Taggart. (1988). The Action Research Planner. Victoria: Deakin University.

Nana Syaodih Sukmadinata. (2007). Landasan Psikologi Proses Pendidikan. Bandung: PT Remaja Rosdakarya.

Rusman, dkk. (2011). Pembelajaran Berbasis Teknologi Informasi dan Komunikasi Mengembangkan Profesionalitas Guru. Rajawali Press: Jakarta.

Shoimin, Aris. (2014). 68 Model Pembelajaran Inovatif dalam Kurikulum 2013. Ar-ruzz Media: Yogyakarta.

Suryabrata, Sumadi. (2010). Psikologi Pendidikan. Rajawali Press: Jakarta. 
